\title{
ANALYSIS OF LOCAL WISDOM AS AN ENVIRONMENTAL CONSERVATION STRATEGY IN INDONESIA
}

\author{
Astri Hasbiah \\ Department of Environmental Engineering, Pasundan University \\ Jl. Dr. Setiabudi No. 193, Bandung 40153, Indonesia \\ astrihasbiah@unpas.ac.id
}

\begin{abstract}
Environmental problems as a result of unsustainable development require holistic solution to be solved. One of the solutions is the reimplementation of local wisdom. In the past, people lived in harmony with the environment and almost all ethnic groups in Indonesia have the wisdom to preserve and manage the environment inherited by their ancestors. Local wisdom is invaluable tradition that has influenced people's attitude and behaviour towards nature. However, this wisdom is abandoned by modern developments. This study aims to analyse the reimplementation of local wisdom as an environmental conservation strategy. Difficulties in learning and using local wisdom practiced in the past are encountered in the reimplementation process. This is due to unavailability of local wisdom official records. Another difficulty is society's unwillingness to re-implement local wisdom. Local wisdom is considered as outdated by many people. Reimplementation of local wisdom can be conducted through systematic approach in education system, integrated socio cultural approach and consistent government development policies. The re-implementation of local wisdom should be adapted to current times. It should not simply adopt local wisdom in the past as it was because it will not suitable with the present time. Renewal of existing local wisdom can be used by the government to create sustainable development. Environmental conservation should be conducted by considering local situation and condition as Indonesia has a very diverse population and environmental conditions.
\end{abstract}

Keywords: environmental conservation; local wisdom. Introduction

Indonesia is not only blessed with natural resources but also with abundant cultural diversity and pluralistic society across the archipelago (Ministry of Environment of Republic Indonesia, 2002). Each community has social resources that are beneficial to development, such as traditional knowledge, wisdom and environmental ethics. In the past, Indonesian local community held strongly to and practiced traditional wisdoms aimed at preserving and safeguarding nature and the environment. The wisdoms are inherited from generation to generation. The local wisdom is often very detailed and accurately guiding the society in developing their life. Local wisdom is proved to be very effective to preserve the environment and ensure compatibility of community and environment. However, modern development seems to be leaving this wisdom behind. Moreover, communities are often excluded from development policy decision making (Baharudin, 2012). As a result of unsustainable development, many places in Indonesia experience environmental problems.

To overcome environmental problems and implement sustainable development, it is recommended to give more attention to social resources that have been proven successful in environmental conservation through reimplementation of local wisdom. This paper aims analyse the reimplementation of local wisdom as environmental conservation strategy.

This research is a descriptive study with case study method. Data collected in this research is secondary data obtained from the literature review. The case study used is in-depth study of the events, environments, and situations that reveal the condition of the society's local wisdom in various locations in Indonesia and other countries during the past and current conditions. This study compare and evaluate the implementation of local wisdom to overcome environmental problems.

\section{Literature Review}

Wisdom is a set of knowledge developed by a group of local community collected from long experience and mutual relationship between human and environment in a sustainable and harmonious rhythm. Local wisdom is knowledge gained from active adaptation with the environment. The knowledge embodied in the form of ideas, activities and equipment. Local wisdom is developed, guided and passed down from generation to generation by the community 
(Ministry of Environment of Republic Indonesia, 2002).

Local wisdom usually has a very deep meaning and closely related to the cultural institutions, particularly religions and customary law. Wisdoms are collection of abstractions experienced by all members of the community and serve as guidance in managing the environment, especially in exploitation of natural resources (Ministry of Environment of Republic Indonesia, 2002)

Many local wisdoms developed by thousands of communities scattered throughout Indonesia. Each community adapts and develops local wisdom as a result of abstraction of experience managing the environment. Often their knowledge of the local environment is very detailed and accurate. It serves as guidelines for the community in developing everyday life. Principally, the original Indonesian culture proved to have a pro-environment philosophy. Almost all ethnic groups and regions in Indonesia have their own local knowledge in preserving the environment (Ministry of Environment of Republic Indonesia, 2002).

However, the wisdom has shifted or degraded as a result of rapid application of advance science and technology, followed by the spread of industry and new social institutions. Existing local wisdom tend to be ignored by the community members. Local wisdom is considered as ineffective factor in development process (Ministry of Environment of Republic Indonesia, 2002). Local wisdom practiced in the past as environmental conservation strategy can be seen in the following examples.

Indigenous people in Tanatowa, Kajang, Bulukumba, South Sulawesi practiced harmonious relationship with nature inherited from their ancestors known as ancestral message. It contains chapters of environmental management methods (Baharudin 2012). The message stated that if the earth is destroyed, the indigenous will also be destroyed. Regarding to this, the indigenous people have their own environmental management system especially in natural resources exploitation method. For example, cultivation should be shared among other community members; they can cut down trees but should provide replacements. Violation of this rule will be subject to customary sanction. Kajang people ancestors' environmental wisdom, knowledge and value are expressed through myths and rituals (Baharudin 2012).

Another example of environmental conservation through local wisdom practices is the Baduy's community in Banten, West Java. The Baduy have sacred responsibility to protect nature from any changes. In order to maintain balance and harmony, The Baduy's live a very simple lifestyle and being moderate in all things until present time. The Baduy's protect the nature with doctrine to run their life straight, preserve the nature, no more and no less. One of the examples of it is the way of The Baduy's respect the forest. They implement taboos for those who want to enter the sacred forest. This has leads the forests well preserved until present time.

Kasa (2011) explains another example of local wisdom implementation of Balinese community which applying Hindu philosophy in developing and implementing environmental conservation programs. The Hindu ceremony aimed at maintaining and conserving the plants is one of the examples. Almost every district in Bali has similar sustainable development concept.

Another example of local wisdom as a way to conserve the environment is showed by Tobelo Dalam tribe in Sulawesi. When the tribe experienced forest ecological problems, they reimplement the forest management wisdom inherited from their ancestors to resolve the problems (Tamalene et al 2014). This shows that reconsider the implementation of local wisdom in managing the environment in the past is necessary to overcome environmental problems. The local wisdom can be seen from the community's view of life and knowledge of the environment.

Another study by Rim-Rukeh, Irerhievwie and Agbozu (2013) explain contribution of local culture practices in forest conservation. Local community preserve holy places using traditional belief. The belief uses taboos that restrict people from the holy places. The practices help enforce environmental conservation especially forest protection and other natural resources.

Kamonthip (2007) study on local wisdom implementation to overcome environmental problems caused by development in Thailand concludes that the way the community solve environmental problems is by collectively studying the problems, recovering remain traditional wisdom and knowledge and then finding the solutions through integrating new knowledge with the inherited local wisdom.

Agmi et al (2014) analyse local wisdom implementation in coral reef management in Kei Besar Island greatly affects the sustainability of coastal areas. Local wisdom has a role in implementation of coastal areas management (Primyastanto et al 2013).

Local wisdom is the solution to environmental problems, as it consists of values to balance and preserve the environment (Fahrianoor et al, 2013). Moreover, local wisdom also protect, appreciate 
and recognise local people's role as the main agents in maintaining and shaping biodiversity. As local wisdom reflected in everyday life, it will be reflected on people's knowledge and practices in utilising and maintaining the environment. Tamalene et al (2014) argue that local wisdom strengthens human and nature relationship. The relationship create emotional attachment and establish mindful attitude. The relationship increases community's awareness of environmental value and importance. Local wisdom will be eternal as long as people maintain and pass it down to the next generation.

Indonesian government recognise the important of local wisdom in environmental management. It confirmed in Law Number 23 of the Environmental Management in 1997 that aspect of human behaviour is integral part in environmental management. Another Indonesian regulation Law number UU RI 32/2009 about Protection and Management of the Environment regulates to develop and maintain culture and local wisdom in order to preserve the environment. The law stated that community's participation and involvement in environmental conservation is important. Therefore, local wisdom should be acknowledge in environmental management policy decision making.

\section{Result and Discussion}

Local wisdom can be use as reference material in implementing sustainable development. Local wisdom was applied as a guidance in managing the environment, especially management of natural resources. Environmental management was developed by considering the importance of social function to ensure community survival (Ministry of Environment of Republic Indonesia, 2002). Sustainable development enables the use of wisdom and social resources as principal in environmental conservations.

Modern development has decreased societies' interest on tradition or culture. Often people assume that tradition or local culture is incompatible with technological progress (Baharudin 2012). However, mutual relationship between human and nature is correlated with development process. It will have reverse effects on the environment. Therefore, there is a need to maintain balance between development and environmental conservation. Human has great influence on environmental changes. Baharudin (2012) argue that local wisdom can be synergised with modern technology in connection with the environmental conservation and sustainable development.
Awareness of nature as the source of human's life will increase when people are aware that they are depending on the environment. This awareness encourages people to create norms that are used as guidelines for their behaviour in managing the environment. The guideline is added with social sanction (Ministry of Environment of Republic Indonesia, 2002). Respect for the environment or the protection of wisdom is the key success of increasing the role of society in the environmental management.

Current absence respect for the environment was developed due to lack of understanding and unavailability of local wisdom information implemented in the past. Moreover, the information is not easily available and accessible (Ministry of Environment of Republic Indonesia, 2002). Therefore, documentation or inventory of local wisdom and traditional knowledge developed by various groups of local community in the entire country is required. Dissemination of local wisdom and traditional knowledge information is also required to be conducted. Globalization and rapid development followed by the spread of new values and application of advanced science and technology has led to obvious degradation on local knowledge. It is necessary to disseminate local knowledge through development of accessible complete data base.

Inventory or documentation efforts, revitalization and legal protection of local wisdom are required. This is important to deal with the rapid growth of development that introduces new values, technology and advanced knowledge. It is also important to empower local communities and to increase participation in environmental management (Ministry of Environment of Republic Indonesia, 2002).

Local wisdom is not only to maintain harmonious relationship between human and the environment but also used as a source of local community's life (Affandy and Wulandari, 2012). Local wisdom is valuable heritage which greatly influence the communities' attitudes and behaviour. Furthermore, Affandy and Wulandari (2012) argue that local wisdom should be considered in a development process. They argue that public policy is aligned with local communities' welfare. Local wisdom is expected to improve local revenues and can achieve optimal decentralization. However, in most cases local governments are unaware of local wisdom benefit in generating society's sustainable income.

Enabling community's involvement in development is not only improve the economy and the role of society in environmental development, but also can enhance the ability of communities' 
social control to access and control the natural resources management. Re-implementation of environmental wisdom and traditional knowledge is an effective way in environment conservation.

Another problem encountered in the reimplementation of local wisdom is local wisdom was designed in the past. It was designed when the total population was relatively small with simple needs and abundant natural resources. Hence, the re-implementation of local wisdom will face different and more complex challenges compared with the situation in the past. The local wisdom reimplementation should be adjusted with current situation and condition. Re-creating the environmental wisdom and traditional knowledge that has been abandoned or degraded due to the influence of the new value should be conducted in a compatible way with present time.

An appropriate step to re-implement the local wisdom is to review the existing wisdom in the community to achieve harmonious relationship with the environment. Tradition and local rules are created and handed down for generations to manage the environment; this can be an important material for the formulation of environmental policy (Ministry of Environment of Republic Indonesia, 2002).

Problem faced in the policy development is that government ignores the importance of tradition or culture in environmental management. Local culture is often considered outdated and often the community involvement is omitted in the development planning (Baharudin 2012). Government should formulate policies and legislation that protects the rights local peoples. Policies and programs should be able to provide access, opportunity and accommodate active role of local peoples in environmental management and utilisation of natural resources. This can also guarantee or protect traditional knowledge of local peoples, such as environmental ethics, environmental wisdom and social institutions.

Environmental management process should consider the local situation and condition (Baharudin, 2012). In Indonesian case, this view is relevant. The values and norms in Indonesia's environmental conservation strategy should consider each region local culture and environment. Local communities in Indonesia have its own concepts of local values in each ethnic group. The values include leadership systems, social relationships, living in groups, the importance of sharing materials and experiences to others, learn continuously from nature, etc. This values can be extracted, explored and formulate for the benefit of nation environmental conservation strategy.
Pluralism of Indonesian society is a driving factor in environmental management. Social and cultural construction are necessary and aimed achieving sustainable social function, economy and ecology. Hence, it can sustain the life of a community or nation. Social capital which contains environmental wisdom is the force of development. It contribute positively in conservation of ecosystem function (Ministry of Environment of Republic Indonesia, 2002).

Different characteristics of each region in Indonesia will require different environmental adaptation strategies. The adaptation strategy is based on the knowledge gained from the experience of adaptation to the environment. Therefore, each community need to develop social capital that is adaptive to the environment. Diversity of environmental management adaptation in Indonesia is caused by Indonesia's diverse society. This factor must be taken into account in planning and implementing sustainable development considering the importance of society's participation in environmental management (Ministry of Environment of Republic Indonesia, 2002).

Yunianto (2012) argues three systematic approaches to develop environmental awareness. The approaches are education, integrated and sustainable socio-culture, and consistent law enforcement. Based on Law no. 32 of 2004, government system in Indonesia is changed from centralized to decentralized systems. This brings opportunity for local government to create sustainable development through revitalisation of existing local wisdom. Important thing to consider by the government is the internalisation of local wisdom values in policy of decision making process.

In addition, Wikantiyoso and Tutuko (2014) stated that local wisdom is also important in the spatial city planning process. As the local wisdom characterizes the city, hence the planning policy should accommodate the local wisdom to develop better city planning. Decentralisation is a good opportunity for re-implementing local wisdom in development policies. This is because local governments have maximum authority to formulate appropriate policies based on local needs. Hence local community positioned as development subject and able to manage local development strategies. An advantage of Local community empowerment is reducing dependencies on central government, develop local potential and preserve local values identity. Therefore, it is important for the government to develop policies based on local wisdom to preserve local culture and natural resources. 
Local community should be regarded as an important actor in government policy decision making, as local wisdom represents the local area character. Inclusion of local wisdom in policy decision making can stimulate local economic development and reduce economic disparities among regions (Affandy and Wulandari, 2012).

Optimum role as development subject should be given to the community. Local community has deep understanding of the area and comprehend the potential to strengthen and develop the area. This can be done through optimising existing social capital supported by local wisdom. Development policies should consider local knowledge as one important aspect to support sustainable development in each region (Affandy and Wulandari, 2012).

Local knowledge is considered to able to bridge the demands of development whilst establishing healthy environment conditions. It is expected that sustainable development can be achieved through local based sustainable development strategy. Local wisdom functions as balancing factor between meetings human needs and environmental conservation. Local community in Indonesia have shown survival capability by preserving natural resources and local traditions. Local community has an optimal role as subjects or actors of regional development. This is because local knowledge strengthens development potential and sustainable development implementation on each decentralise area (Siswandi 2003).

\section{Conclusion}

Affandy and Wulandari (2012) argue that local communities' wisdom and traditional knowledge has important role in environmental conservation strategies. Local wisdom is an important part in the development strategy as it affects environmental sustainability. Local wisdom greatly influences the attitudes and behaviour of local community. Reimplementation of local wisdom can create sustainable development as local wisdom represents local area character and stimulate local economic development (Ministry of Environment of Republic Indonesia, 2002).

Culture provides a clear illustration of how to maintain nature continuously. The environmental wisdom can be used as a handbook for communities to implement sustainable development. Hence, the government also need to make the environmental wisdom as reference material in the development plan (Ministry of Environment of Republic Indonesia, 2002). Reimplementation of local wisdom can be conducted through systematic approach in education system, integrated socio cultural approach and consistent government development policies. Moreover, environmental management approach should be conducted by considering local situation and condition. This is due to the facts that each region have different culture (Ministry of Environment of Republic Indonesia, 2002). Furthermore, the reimplementation of local wisdom should be adapted to current times. It should not simply adopt local wisdom in the past as it was because it will not suitable with present time.

\section{References}

1) Affandy D and Wulandari P, 2012, An exploration local wisdom priority in public budgeting process of local government case study in east java, int. J. Eco. Res., 2012v3i5, 61-76 issn: 2229-6158

2) Agmi S, Beruat P, aziz nur bambang ambariyanto, 2014, The condition of coral reef and local wisdom in kei besar north east district (coastal resources management model based on local wisdom in the kei besar district of north east, southeast maluku regency), Journal of environment and ecology Issn 2157-6092 2014, vol. 5 , no. 1

3) Baharudin E, 2012, Kearifan Lokal, Pengetahuan Lokal dan Degradasi Lingkungan, Universitas Esa Unggul http://www.esaunggul.ac.id viewed 14 april 2015

4) Fahrianoor, Windari T, Taharuddin, Mar'I R, and Maryono, 2013, The practice of local wisdom of dayak people in forest conservation in south Kalimantan Indonesian, journal of wetlands environmental management issn 23545844 Volume 1, number 1, september 2013

5) Indonesian law number 23/1997 of the Environmental Management.

6) Indonesian law number 32 of 2004 of decentralisation of local government.

7) Indonesian Law number 32/2009 of Protection and Management of the Environment

8) Kamonthip K, 2007 Local wisdom, environmental protection and community development: the clam farmers in tambon bangkhunsai, phetchaburi province, Thailand Manusya: journal of humanities 10.1, 2007.

9) Kasa I W, 2011, Local wisdom in relation to climate change, J. Issaas vol. 17, no. 1:22-27.

10) Ministry of Environment of Republic Indonesia 2002, Bunga rampai kearifan lingkungan, Ministry of Environment of Republic Indonesia.

11) Primyastanto $M$, Muhammad $S$, Soemarno, and Efani A, 2013, Fisheries resources management by empowering the local Wisdom in madura straits, Research on humanities and social sciences www.iiste.org Issn 2222-1719 (paper) issn 2222-2863 (online) Vol.3, no.6, 2013

12)Rim-Rukeh. A, G. Irerhievwie and I. E. Agbozu, 2013, Traditional Beliefs and 
Conservation of Natural Resources: International Journal of Biodiversity and Conservation, 5 (7): 426-432.

13)Tamalene, M.H, Al muhdhar, Suarsini E, Rochman F, 2014, The practice of local wisdom of tobelo dalam (togutil) tribal community in forest conservation in Halmahera, Indonesia. International journal of plant research 2014, 4(4a): 1-7 doi: 10.5923/s.plant.201401.01

14)Wikantiyoso $R$ and Tutuko $P$, Editorial introduction Special issue on local wisdom for better city planning

\section{First Author}

Astri Hasbiah graduated from Macquarie University with Master of Environment degree specialising in environmental studies in 2014 and Bachelor of Environmental Engineering from Pasundan University in 2005. She is currently working as lecturer at Pasundan University, Department of Environmental Engineering and part of team of Environmental Research and Assessment Centre. Her research interests are environmental education and environmental economics 